\title{
Ileal digestibility of pea and faba bean carbohydrates in growing pigs*
}

\author{
Jolanta Gdala and Lucyna Buraczewska \\ The Kielanowski Institute of Animal Physiology and Nutrition, \\ Potish Academy of Sciences \\ 05-110 Jablonna, Poland
}

(Received 13 March 1997; accepted 15 May 1997)

\begin{abstract}
The experiment was carried out on six pigs with an initial body weight of about $34 \mathrm{~kg}$. The pigs were fitted with a simple $\mathrm{T}$-shape cannula and fed on six semisynthetic diets containing sucrose and legume seed meal as the main components. Faba bean (cvs Kamir and Alen), white-flowered pea (cvs Kwestor and Sol) and coloured-flowered pea (cvs Fidelia and Vatra) seeds were the only source of polysaccharides and protein for the experimental animals.

Ileal digestibility of pea starch ranged from 85 to $87 \%$ and was similar for all the tested cultivars. The starch digestibility of faba bean was $86 \%$ for cv Alen and $82 \%$ for cv Kamir. Digestibility of pea and faba bean protein varied from 70 to $74 \%, \alpha$-galactosides of faba beans were microbiologically hydrolyzed up to $83 \%$, and those of pea seeds up to $93 \%$ in the small intestine. Digestibility of non-starch polysaccharides averaged $39 \%$ for faba beans and from 27 to $43 \%$ for the pea cultivars. No differences were found between the two types of pea, indicating that tannins of the coloured-flowered pea did not interfere with ileal digestion of major nutrients fed to pigs.
\end{abstract}

KEY WORDS: pea, faba bean, ileal digestibility, pigs, carbohydrates

\section{INTRODUCTION}

Dietary nutrients, except cell wall polysaccharides, are extensively digested and absorbed in the small intestine of pigs. Most cell wall polysaccharides can be degraded only by microbial enzymes, mainly in the hindgut. The extent of the

\footnotetext{
* The research was financed by grant No 5 \$305 03305 from the Committee for Scientific Research
} 
pre-caecal and post-ileal digestion of nutrients results in differences in the utilisation of energy. In pigs energy utilisation falls as the proportion of post-ileal fermentation to pre-caecal digestibility raises (Just et al., 1983).

Starch is thought to be completely digested up to the end of the small intestine of monogastric species. However, in the observations of Gdala et al. (1991) on digestibility of polysaccharides in pigs fed on diets containing 52 and $42 \%$ barley and pea seeds, respectively, ileal digestibility of starch ranged from 85 to 93 per cent. Assuming that cereal starch is highly digestible, over $97 \%$ according to Bach Knudsen (1991), these results can suggest much lower digestibility of pea starch as compared to cereal starch. Also the results of assessing starch bioavailability in the upper gastrointestinal tract of colectomized rats indicated highly significant differences in food starch digestibility. It was reported that $15.2 \%$ of pea starch, but only $0.2 \%$ of that from rice, was recovered in the ileal digesta of rats (Hildebrandt and Marllet, 1991).

Pea and faba bean are known to contain different factors that affect their nutritional value. Among them tannins have often been described as the most important from the nutritional point of view. They are known to form complexes with dietary protein reducing its digestibility and/or inhibiting the activity of digestive enzymes (Jansman et al., 1992).

The aim of the present experiment was to study the ileal digestibility of starch and other carbohydrates of pea and faba beans in pigs fed on diets in which the legume seeds were the only, except sucrose, source of carbohydrates. For comparison, enzyme susceptible starch was determined in vitro.

\section{MATERIAL AND METHODS}

Seeds

Seeds of two cultivars (Kamir and Alen) of faba bean (Vicia faba L.), two cultivars (Kwestor and Sol) of white-flowered pea (Pisum sativum hortense), and two cultivars (Fidelia and Vatra) of coloured-flowered pea (Pisum sativum arvense) were used in the present study. Pea seeds originated from the Plant Breeding Stations at Wiatrowo and faba beans from The Plant Breeding Station at Szelejewo. Both stations are located in Western Poland.

\section{Animals}

The experiment was carried out on six castrated male pigs (Polish Landrace) from 34 to $64 \mathrm{~kg}$ body weight. Following five days adaptation to the cages, the pigs were surgically fitted with a post valvular T-caecum (PVTC) cannula 
according to van Leeuwen et al. (1991). After a recovery period of seven days the pigs were fed for two weeks on faba bean diets. Afterwards, the pigs were adapted to pea diets ( 7 days) and fed on them for the next four weeks. Both experiments were carried out according to a change-over design (each diet was given to 6 pigs). Ileal digesta was collected during the last three days of feeding each experimental diet.

\section{Diets}

Pigs were fed on semisynthetic diets containing sucrose and legume seed meals as the main components (Table 1). The level of faba bean and pea included into the diets supplied $160 \mathrm{~g} \mathrm{~kg}^{-1}$ of protein. The feeding level was equal to 3 times the pigs' maintenance requirement for metabolisable energy (ARC, 1981). Diets were fed in meal form, twice a day at 8:00 and 20:00 h, mixed with water at a ratio of $1: 1$.

TABLE 1

Composition of the experimental diets, $\mathrm{g} / \mathrm{kg}$

\begin{tabular}{lrrrrrrr}
\hline \multirow{2}{*}{ Components } & \multicolumn{2}{c}{ Faba bean } & & \multicolumn{4}{c}{ Pea } \\
\cline { 2 - 3 } \cline { 8 - 9 } & Kamir & Alen & & Kwesior & Sol & Fidelia & Vatra \\
\hline Faba bean & 620.00 & 620.00 & - & - & - & - \\
Pea & - & - & 737.70 & 831.20 & 782.80 & 802.40 \\
Sucrose & 327.48 & 327.48 & & 204.79 & 111.29 & 159.69 & 140.09 \\
Soya oil & 10.00 & 10.00 & & 10.00 & 10.00 & 10.00 & 10.00 \\
Mineral-vitamin mixture & 38.00 & 38.00 & & 43.00 & 43.00 & 43.00 & 43.00 \\
Chromium oxide & 3.00 & 3.00 & & 3.00 & 3.00 & 3.00 & 3.00 \\
DL-Met & 1.40 & 1.40 & & 1.26 & 1.26 & 1.26 & 1.26 \\
DL-Trp & 0.12 & 0.12 & & 0.25 & 0.25 & 0.25 & 0.25 \\
\hline
\end{tabular}

\section{Digesta collection}

Ileal digesta was collected for $12 \mathrm{~h}$ per day $(8.00-20.00 \mathrm{~h})$ using plastic bags connected to the cannulas. The bags were changed at least every hour and their contents were immediately frozen in plastic containers at $-20^{\circ} \mathrm{C}$. After completion of the collections, samples were thawed, pooled per animal within each experimental period, freeze-dried and ground $(0.5 \mathrm{~mm})$ before chemical analysis.

\section{Analytical procedures}

Dry matter (DM), crude protein ( $\mathrm{N} \times 6.25)$, ether extract, crude fibre (CF), total starch and ash were analysed using standard methods (AOAC, 1990). 
Enzyme susceptible starch was determined according to procedure of Megazyme, Australia (TSA/92). The content of neutral detergent fibre (NDF), acid detergent fibre (ADF) and acid detergent lignin (ADL) was determined using Fibertec System M by methods described by Van Soest and Wine (1967) and Van Soest (1973). Sucrose, $\alpha$-galactosides (raffinose, stachyose and verbascose), total non-starch polysaccharides (NSP) and their constituent sugars were determined according to methods described in our earlier publication (Gdala and Buraczewska, 1996). Condensed tannins were determined according to the procedure of Kuhla and Ebmeier (1981).

\section{Statistical analysis}

The ileal digestibility values for dry matter, protein, fibre fractions, oligosaccharides and NSP in faba beans and pea seeds were statistically analysed using analysis of variance taking into account as a factor the faba bean or pea cultivar. Statistical analysis was performed using Statgraphics Plus v. 7.0 (1993).

\section{RESULTS AND DISCUSSION}

\section{Chemical composition of faba bean and pea seeds}

The chemical composition of the tested faba beans and peas is presented in Table 2. The content of crude protein, total starch and enzyme susceptible starch was similar in the tested cultivars of faba bean and accounted on average for 295 , 413 and $355 \mathrm{~g} \mathrm{~kg}^{-1}$, respectively. As determined, the enzyme susceptible starch constituted $86 \%$ of total starch. No significant differences between faba beans were found in the content of NSP, NDF, ADF or ADL. Cellulose, calculated as the difference between ADF and ADL, constituted a considerable proportion (about $92 \mathrm{~g} \mathrm{~kg}^{-1} \mathrm{DM}$ ) of faba bean cell wall polysaccharides. Hemicelluloses were found at low level of 27 and $28 \mathrm{~g} \mathrm{~kg}^{-1} \mathrm{DM}$ for cv Kamir and Alen, respectively. Slightly higher levels of hemicelluloses in faba bean (about $40 \mathrm{~g} \mathrm{~kg}^{-1} \mathrm{DM}$ ) were reported previously by Cerning-Beroard and Filiatre (1976). The content and chemical composition of faba bean NSP was similar to that presented by Gdala and Buraczewska (1997).

No evident differences in the composition, but tannin content, were observed between white- and coloured-flowered varieties of pea. In comparison with the faba bean cultivars the peas contained less protein $(220-224 \mathrm{~g})$ but more total starch $(443-501 \mathrm{~g})$ with a similar mean proportion $(86 \%)$ of the enzymesusceptible one. The crude protein level in pea seeds was within the range of values (145-280 $\mathrm{g} \mathrm{kg}^{-1} \mathrm{DM}$ ) presented by Gdala et. al. (1992). However, the 
TABLE 2

Chemical composition of faba beans and pea seeds, $\mathrm{g} / \mathrm{kg} \mathrm{DM}$

\begin{tabular}{lrrrrrrrr}
\hline \multirow{2}{*}{ Indices } & \multicolumn{2}{c}{ Faba bean } & & \multicolumn{3}{c}{ Pea } \\
\cline { 2 - 5 } \cline { 7 - 8 } & Kamir & Alen & & Kwestor & Sol & Fidelia & Vatra \\
\hline Weight of 1000 secds, g & 610 & 563 & & 238 & 256 & 186 & 184 \\
Dry matter & 878 & 881 & & 890 & 875 & 887 & 886 \\
Crude protein & 298 & 292 & & 244 & 220 & 231 & 225 \\
Ether extract & 15 & 10 & & 12 & 15 & 13 & 14 \\
Crude fibre & 87 & 101 & & 57 & 60 & 60 & 61 \\
Ash & 37 & 38 & & 31 & 33 & 34 & 301 \\
Total starch & 418 & 408 & & 475 & 481 & 443 & 501 \\
Enzyme susceptible starch & 360 & 350 & & 400 & 439 & 383 & 381 \\
$\alpha$-Galactosides & 24 & 31 & & 64 & 48 & 63 & 66 \\
Fibre fraction: & & & & & & & \\
$\quad$ NSP & 209 & 208 & & 167 & 178 & 183 & 163 \\
$\quad$ NDF & 142 & 145 & & 132 & 139 & 157 & 143 \\
$\quad$ ADF & 115 & 117 & & 81 & 85 & 88 & 87 \\
$\quad$ ADL & 18 & 24 & & 4 & 5 & 10 & 8 \\
$\quad$ hemicelluloses & 27 & 28 & & 50 & 54 & 68 & 56 \\
Tannins & 6.70 & 5.92 & 0.37 & 0.38 & 6.29 & 4.62 \\
\hline
\end{tabular}

TABLE 3

Content of oligosaccharides and non starch polysaccharides (NSP) in faba beans and pea seeds, $\mathrm{g} / \mathrm{kg} \mathrm{DM}$

\begin{tabular}{|c|c|c|c|c|c|c|}
\hline \multirow{2}{*}{ Components } & \multicolumn{2}{|c|}{ Faba bean } & \multicolumn{4}{|c|}{ Pea } \\
\hline & Kamir & Alen & Kwestor & Sol & Fidelia & Vatra \\
\hline \multicolumn{7}{|l|}{ Oligosaccharides: } \\
\hline sucrose & 22.8 & 27.0 & 21.3 & 27.6 & 18.8 & 14.2 \\
\hline raffinose & 2.7 & 3.7 & 10.4 & 10.0 & 7.9 & 8.4 \\
\hline stachyose & 7.7 & 9.4 & 38.3 & 22.4 & 33.7 & 38.6 \\
\hline verbascose & 13.2 & 17.6 & 14.8 & 15.9 & 21.1 & 18.8 \\
\hline total $\alpha$-galactosides & 23.6 & 30.7 & 63.5 & 48.2 & 62.7 & 65.8 \\
\hline \multicolumn{7}{|l|}{ NSP: } \\
\hline rhamnose & 2.6 & 2.3 & 1.7 & 1.9 & 1.2 & 1.5 \\
\hline fucose & 0.1 & 0.1 & 0.6 & 0.7 & 0.7 & 0.7 \\
\hline arabinose & 35.1 & 33.5 & 34.7 & 33.4 & 35.9 & 29.6 \\
\hline xylose & 31.5 & 22.9 & 15.8 & 12.2 & 11.4 & 11.1 \\
\hline mannose & 1.1 & 1.8 & 1.3 & 1.8 & 1.6 & 1.5 \\
\hline galactose & 17.7 & 18.8 & 14.3 & 14.8 & 15.8 & 14.2 \\
\hline glucose & 94.0 & 94.9 & 75.1 & 80.9 & 92.4 & 79.7 \\
\hline uronic acids & 27.2 & 33.7 & 23.1 & 31.9 & 23.7 & 24.5 \\
\hline total NSP & 209.3 & 208.0 & 166.7 & 177.6 & 182.6 & 162.6 \\
\hline
\end{tabular}


content of total starch was higher than that in peas (410-436 $\left.\mathrm{g} \mathrm{kg}^{-1} \mathrm{DM}\right)$ used in the study of Bengala Freire et al. (1991), but similar to that in peas introduced in pig diets used by Abrahamsson et al. (1993) in a digestibility experiment. Of the fibre fractions, peas contained less NSP (163-183 g), ADF (81-88 g) and ADL (4-10 g) but more hemicelluloses (50-68 g) than the faba beans. Similarly in both species, the monosaccharide residues of glucose, arabinose and uronic acids dominated in the NSP fraction (Table 3 ). Faba beans contained the relatively lowest level of $x$-galactosides ( 24 and $31 \mathrm{~g} \mathrm{~kg}^{-1} \mathrm{DM}$ ) among legume seeds, which is in agreement with literature data (Sosulski et al., 1982). An $\alpha$-galactoside level nearly double that of faba beans was found in peas (48-66 g). Some differences were also observed in their composition: verbascose was dominant in faba beans, while stachyose and verbascose in peas, which supports our previous results (Gdala and Buraczewska, 1997).

\section{Ileal digestibility of pea and faba bean nutrients}

Ileal digestibility of crude protein of pea seeds and faba beans was similar and ranged from 70 to $74 \%$ (Tables 4 and 5), although the content of condensed tannins in seeds of white-flowered peas was significantly lower (on average $\left.0.38 \mathrm{~g} \mathrm{~kg}^{-1} \mathrm{DM}\right)$ than that in coloured-flowered peas $\left(5.46 \mathrm{~g} \mathrm{~kg}^{-1} \mathrm{DM}\right)$ and faba beans $\left(6.32 \mathrm{~g} \mathrm{~kg}^{-1} \mathrm{DM}\right)$. Therefore, it seems that in the present experiment condensed tannins did not considerably affect protein digestibility in seeds of coloured-flowered peas and faba beans. The digestibility coefficients of protein are in agreement with values previously reported by Grala et al. (1993).

The average ileal starch digestibility was $86 \%$ in peas and $84 \%$ in faba beans. The digestibility values are similar to the proportion of the enzyme-susceptible starch in total digestibility (about $86 \%$ ). According to Colonna and Mercier (1979) peas are characterized by the presence of about $20 \%$ of resistant starch. However, other authors (Bengala Freire et al. 1991a) found under $6 \%$ undigested pea starch or about $5 \%$ undigested faba bean starch at the ileal level of pigs. Somewhat lower ileal digestibility of starch (about $90 \%$ ) could be predicted for two peas basing on the data received by Abrahamsson et al. (1993). The low digestibility of pea starch ( $76 \%$ ) found by Longstaff and McNab (1987) in an experiment on adult cockerels was attributed to poor contact between enzyme and starch in the birds digestive tract. According to Hildebrandt and Marllet (1991) raw starch of legume seeds may resists digestion to some extent in the small intestine of nonruminant animals. This is probably related to starch nature, physical entrapment of starch within a food and retrogradation through food processing (Würsch et al., 1986; Colonna et al., 1992). Legumes contain 30 to $40 \%$ amylose and 60 to $70 \%$ amylopectin in their starch granules, while most other carbohydrate foods contain 15 to $25 \%$ amylose and 75 to $85 \%$ amylopectin 
TABLE 4

Ileal digestibility of dry matter. crude protein and fibre fractions in pigs fed on pea dicts, $\%$

\begin{tabular}{lcccccc}
\hline \multirow{2}{*}{ Components } & \multicolumn{3}{c}{ Diet } & SEM & P $\leqslant$ \\
\cline { 2 - 6 } & Kwestor & Sol & Fidelia & Vatra & \\
\hline Dry matter & 68.8 & 65.7 & 66.4 & 65.4 & 0.64 & 0.142 \\
Crude protein & 71.7 & 74.0 & 71.3 & 69.9 & 0.57 & 0.110 \\
Total starch & 85.6 & 85.2 & 87.3 & 86.6 & 0.71 & 0.718 \\
Fibre fraction: & & & & & & \\
$\quad$ NSP & $36.6^{\mathrm{ah}}$ & $43.1^{\mathrm{a}}$ & $36.7^{\mathrm{ab}}$ & $26.6^{\mathrm{b}}$ & 1.34 & 0.004 \\
$\quad$ NDF & $48.9^{\mathrm{a}}$ & $48.8^{\mathrm{a}}$ & $31.7^{\mathrm{b}}$ & $42.5^{\mathrm{a}}$ & 1.38 & 0.001 \\
$\quad$ ADF & 25.2 & 21.0 & 21.3 & 21.7 & 1.32 & 0.378 \\
$\quad$ hemicelluloses & $71.8^{\mathrm{d}}$ & $71.0^{\mathrm{a}}$ & $48.0^{\mathrm{b}}$ & $67.1^{\mathrm{a}}$ & 2.00 & 0.010 \\
\hline
\end{tabular}

$a, b-P \leqslant 0.05$

TABLE 5

Ileal digestibility of dry matter, crude protein and fibre fractions in pigs fed on faba bean diets, $\%$

\begin{tabular}{lcccc}
\hline \multirow{2}{*}{ Components } & \multicolumn{2}{c}{ Diet } & SEM & P \\
\cline { 2 - 3 } & Kamir & Alen & & \\
\hline Dry matter & 72.4 & 71.8 & 0.36 & 0.376 \\
Crude protein & 71.3 & 70.3 & 0.67 & 0.898 \\
Total starch & 81.5 & 86.4 & 0.91 & 0.060 \\
Fibre fraction: & & & & \\
$\quad$ NSP & 38.3 & 39.2 & 1.80 & 0.056 \\
$\quad$ NDF & 20.2 & 25.6 & 1.04 & 0.066 \\
$\quad$ ADF & 16.3 & 16.8 & 2.03 & 0.568 \\
$\quad$ hemicelluloses & 31.0 & 56.4 & 1.51 & 0.224 \\
\hline
\end{tabular}

(Nowotny, 1969). Sandstedt et al. (1962) reported that raw wrinkled pea starch with $65 \%$ amylose was less susceptible to pancreatic digestion than maize starch containing from 0 to $47 \%$ amylose. Moreover, the rate of hydrolysis of high amylose $(63 \%)$ maize starch in vitro was less than that of the normal one $(25 \%)$. Thorne et al. (1983) suggested that the difference in the digestibility rate between amylose and amylopectin starches may be due to the larger surface area of amylopectin which, therefore, is more available for amylolytic attack. The digestion rate of purified starch from bean and pea in vitro was slower than that of rice (Würsch et al., 1986). Also homogenized/autoclaved pea products showed higher levels of undigestible starch than potato products, which is probably related to the higher amylose/amylopectin ratio in pea than in potato starch (Björck and Siljeström, 1992). 
TABLE 6

Ilcal digestibility of oligosaccharides and non-starch polysaccharides (NSP) in pigs fed on pea dicts, \%

\begin{tabular}{|c|c|c|c|c|c|c|}
\hline \multirow{2}{*}{ Components } & \multicolumn{4}{|c|}{ Diet } & \multirow[t]{2}{*}{ SEM } & \multirow[t]{2}{*}{$P \leqslant$} \\
\hline & Kwestor & Sol & Fidelia & Vatra & & \\
\hline \multicolumn{7}{|l|}{ Oligosaccharides: } \\
\hline sucrose & $97.4^{\mathrm{ab}}$ & $98.1^{3}$ & $96.1^{\text {a }}$ & $94.9^{\mathrm{b}}$ & 0.33 & 0.013 \\
\hline raffinose & $92.2^{\mathrm{a}}$ & $85.7^{\mathrm{a}}$ & $59.8^{\mathrm{b}}$ & $83.6^{\mathrm{a}}$ & 1.66 & 0.001 \\
\hline stachyose & $94.6^{\mathrm{a}}$ & $86.3^{\mathrm{ab}}$ & $79.7^{\mathrm{b}}$ & $92.6^{\mathrm{ab}}$ & 1.63 & 0.023 \\
\hline verbascose & $90.3^{a}$ & $88.9^{2}$ & $77.5^{\mathrm{b}}$ & $92.0^{\mathrm{a}}$ & 1.21 & 0.003 \\
\hline total $\alpha$-galactosides & $93.2^{\mathrm{a}}$ & $87.1^{\mathrm{4}}$ & $73.8^{\mathrm{b}}$ & $91.3^{a}$ & 1.14 & 0.001 \\
\hline \multicolumn{7}{|l|}{ NSP: } \\
\hline arabinose & $34.0^{a}$ & $38.7^{a}$ & $27.6^{\mathrm{ab}}$ & $14.1^{b}$ & 2.45 & 0.014 \\
\hline xylose & $24.1^{\text {ab }}$ & $28.4^{\mathrm{a}}$ & $23.2^{\mathrm{ab}}$ & $12.7^{\mathrm{b}}$ & 1.58 & 0.041 \\
\hline galactose & $36.3^{\mathrm{b}}$ & $53.4^{\mathrm{a}}$ & $39.6^{\mathrm{ab}}$ & $48.9^{\mathrm{ab}}$ & 1.72 & 0.008 \\
\hline glucose & $45.7^{\mathrm{a}}$ & $53.7^{\mathrm{a}}$ & $43.1^{\mathrm{i}}$ & $29.2^{\mathrm{b}}$ & 1.38 & 0.001 \\
\hline uronic acids & 38.2 & 33.4 & 35.2 & 34.1 & 1.22 & 0.574 \\
\hline
\end{tabular}

$\mathrm{a}, \mathrm{b}-\mathrm{P} \leqslant 0.05$

TABLE 7

Ileal digestibility of oligosaccharides and non-starch polysaccharides (NSP) in pigs fed on faba bean diets, $\%$

\begin{tabular}{lllll}
\hline \multirow{2}{*}{ Components } & \multicolumn{2}{c}{ Diet } & SEM & P \\
\cline { 2 - 3 } & Kamir & Alen & \\
\hline Oligosaccharides: & & & & \\
$\quad$ sucrose & 97.7 & 98.7 & 1.15 & 0.279 \\
$\quad$ raffinose & 68.4 & 77.7 & 5.90 & 0.456 \\
stachyose & 72.2 & 78.4 & 7.70 & 0.702 \\
verbascose & 73.3 & 83.2 & 5.54 & 0.428 \\
total $x$-galactosides & 75.1 & 82.7 & 5.98 & 0.547 \\
NSP: & & & & \\
arabinose & 45.1 & 42.3 & 2.21 & 0.547 \\
$\quad$ xylose & 63.8 & 55.6 & 1.57 & 0.029 \\
galactose & 60.9 & 62.4 & 1.05 & 0.503 \\
glucose & 31.5 & 34.0 & 1.89 & 0.012 \\
$\quad$ uronic acids & $15.6^{\mathrm{b}}$ & $36.2^{\mathrm{a}}$ & 2.47 & 0.003 \\
\hline
\end{tabular}

$a, b-P \leqslant 0.05$

As concerns pea fibre fractions, the coloured-flowered peas showed somewhat lower digestibility than the white-flowered cultivars. The lowest NSP digestibility $(27 \%)$ was observed after feeding cv Vatra, but the lowest disappearance of NDF $(32 \%)$ and hemicelluloses $(48 \%)$ was noted for cv Fidelia. The degree of fermentation of faba bean NSP was similar to that observed for peas. However, 
NDF and ADF were degraded to a much lesser extent, on average 23 and $17 \%$, respectively. In the study of Shi and Noblet (1994), the mean ileal digestibility of NDF and ADF in pigs ( $44 \mathrm{~kg}$ body weight) fed on six cereal-based diets (the average content of NDF and ADF was 151 and $63 \mathrm{~g} / \mathrm{kg} \mathrm{DM}^{-1}$ ) was about 16 and $4 \%$, respectively. Differences between the tested legume species are also reflected in the rate of disappearance of NSP monosugars; that of xylose and galactose was much higher for faba bean than for pea (Tables 6 and 7). In the case of the peas, xylose digestibility appeared to be lower than other NSP components. Drochner (1984), demonstrated a certain breakdown of NSP, such as hemicelluloses and pectic substances in the stomach and in the small intestine of pigs.

All $\alpha$-galactosides were intensively fermented in the small intestine of pigs. Their digestibility ranged from 74 to $93 \%$ for peas and was lowest $(P<0.001)$ for cv Fidelia. Despite the lower level of these oligosaccharides in field beans than in pea seeds, their loss was similar and accounted for 75 and $83 \%$ for cvs Kamir and Alen, respectively. Generally, the present results are consistent with those found for peas (Bengala Freire et al., 1991a) and for lupins (Gdala at al., 1997) and prove the intensive breakdown of $\alpha$-galactosides in the upper part of pig's digestive tract after feeding legume seeds.

\section{CONCLUSIONS}

Peas and faba beans are potentially useful sources of energy and protein in pig feeding. The level of starch is high and ranges from 400 to $500 \mathrm{~g} / \mathrm{kg}^{-1} \mathrm{DM}$, however, from 13 to $18 \%$ of the legume seed starch was resistant to enzymatic digestion in the small intestine. The level of $\alpha$-galactosides is higher in pea seeds than in faba beans and these sugars are easily fermented already in the small intestine, which can be a cause, of flatulence in pigs. Among fibre fractions, ADF, NDF and hemicelluloses of pea varieties were fermented to a greater extent than those of faba beans. Although the level of condensed tannins was much higher in coloured-flowered field beans and peas than in white-coloured peas, no differences were found in protein or starch digestibility between these legumes.

\section{REFERENCES}

Abrahamsson M., Graham H., Daveby Y.D., Aman P., 1993. Ileal and faecal digestibility of light or dark coloured peas (Pisum sativum) in growing pigs. Anim. Feed. Sci. Technol. 42,15-24

AOAC, 1990. Official Methods of Analysis of the Association of Official Analytical Chemists. 15th Edition, Chapter 32, Washington, DC

ARC, 1981. Agricultural Research Council. The Nutrient Requirements of Pigs. Commonwcalth Agricultural Bureaux, Slough, UK 
Bach Knudsen K.E., 1991. Breakdown of plant polysaccharides in the gastrointestinal tract of pigs. EAAP Publication No 54, 428-433

Bengala Freire J., Aumaitre A., Peiniau J., 1991. Effects of feeding raw and extruded peas on ileal digestibility, pancreatic enzymes and plasma glucose and insulin in early weand pigs. J. Anim. Physiol. Anim. Nutr. 65, 154-164

Bengala Freire J., Aumaitre A., Peiniau, J. I ebreton Y., 199la. Apparent ileal digestibility of starch and $\alpha$-galactosides from peas by early weaned pigs: effect of extrusion. EAAP Publication No. 54 , pp. $395-400$

Björck I, M. N., Siljeström M. A., 1992, In-vivo and in-vitro digcstibility of starch in autoclaved pea and potato products. J. Sci. Food Agric. 58, 541-553

Cerning-Beroard J., Filiatre $\Lambda$., 1976. A comparison of the carbohydrate composition of legume sceds: horse beans, peas and lupins. Cercal Chcm, 53, 968-978

Colonna P., Mercier C., 1979. Les amidons de légumincuses: aspects, composition, structure et properiétés physico-chimiques. Lebensm. Wiss. Technol. 12, 1-12

Colonna P., Buleon A., Doublier J.L., 1992. Structural features of smooth and wrinkled ped starches. Proceedings of 1st European Conference on Legume Grains, Angers (France), pp. 401-402

Drochner W., 1984. Einfluss wechseln der Rohfaser- und Pcktingchalte auf cinige Verdauungsvorgange beim wachsendem Schwein. Z. Tierphysiol., Tierernähr., Futtermitlelk., Suppl. Nr 14

Gdala J., Buraczewska L,, 1996. Chemical composition and carbohydrate content of seeds from several lupin species. J. Anim. Feed Sci. 5, 403-416

Gdala J., Buraczewska L., 1997. Chemical composition and carbohydrate content of several varieties of faba bean and pea seeds. J. Anim. Feed Sci. 6, 123-135

Gdala J., Buraczewska L., Grala W., 1992, The chemical composition of different types and varieties of pea and the digestion of their protein in pigs. J. Anim. Feed Sci. 1, 71-79

Gdala J., Graham H., Buraczewska L., $\AA$ man P., 1991. Ileal and faecal digestibility of polysaccharides in pigs fed on diets with different varieties of pea. EAAP Publication No 54, 446-451

Gdala J., Jansman A.J.M., Buraczewska L., Huisman J.. van Leeuwen P.. 1997. The influence of $\alpha$-galactosidase supplementation on the ileal digestibility of lupin seed carbohydrates and dietary protein in young pigs. Anim. Feed Sci. Technol. (accepted)

Grala W.. Jansman A.J.M., van Leeuwen P., Huisman J., van Kempen G.J.M., Verstegen M.W.A. 1993. Nutritional value of raba beans (Vicia faba L.) led to young pigs. J. Anim. Feed Sci. 2, 169-179

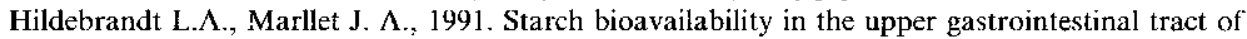
colectomized rats. J. Nutr. 121, 679-86

Jansman A.J.M., Enting H., Huisman J., Verstegen M.W.A., 1992. The effects of condensed tannins in faba beans (Vicia faba L.) on the activity of trypsin and chymotrypsin in duodenal and ileal chyme in pigs. Proceedings of lst European Conference on Grain Legume, Angers (France), pp. 483-484

Just A., Fernandez J.A., Jorgensen H., 1983. The net encrgy value of diets for growth in pigs in relation to the fermentative processes in the digestive tract and the site of absorption of the nutrients. Livest. Prod. Sci. 352-357

Kuhla S., Ebmeier C., 1981. Unterschungen zum Tanningehalt in Ackerbohnen. Arch. Tierenähr. 31, 573-588

Longstaff M., Mcnab J.M., 1987. Digestion of starch and fibre carbohydrates in peas by adult cockerels. Brit. Poultry Sci. 28, 261-285

Megazyme, 1992. Enzyme Susceptible Starch Assay Procedure, TSA/92, Australia

Nowotny F., 1969. Starch (in Polish). Wydawnictwa Naukowo-Techniczne, Warszawa, pp. 18-34

Shi X.S., Noblet J., 1994. Effect of body weight and fecd composition on the contribution of hindgut to digestion energy and nutrients in pigs. Livest. Prod. Sci. 38, 225-235

Sosulski F., Elkowicz L., Reichert R. D., 1982. Oligosaccharides in eleven legumes and their air-classified protein and starch fractions. J. Food Sci. 47, 498-502 
Statgraphics Plus vr 7.0 for DOS, 1993. Statistical Graphics System by Graphics Corporation Thorne M.J., Thompson L.U, Jenkins D.A., 1983. Factors affecting starch digestibility and the glycemic response with special reference to legumes. Amer. J. Clin. Nutt. 38, 481-488

Van der Poel A.F.B., Gravendeel S., van Kleef D.J., Jansman A.J.M., Kemp B., 1992. Tannincontaining faba beans (Vicia faba L.): effects of methods of processing on ileal digestibility of protein and starch for growing pigs. Anim. Feed Sci. Technol. 36, 205-214

Van Leeuwen P., van Kleef D., van Kempen G. J. M., Huisman J., Verstegen M. W. A., 1991. The post valve-caecum cannulation technique in pigs applied to determine the digestibility of amino acids in maize, groundnut and sunflower meal. J. Anim. Physiol. Anim. Nutr. 65, 183-193

Van Soest P., Wine R.H., 1967. Use of detergents in the analysis of fibrous feeds. IV. Determination of plant cell constituents. J. Assoc. Off. Agric. Chem. 50, 50-55

Van Soest P., 1973. Collaborative study of acid detergent fibre and lignin. J. Assoc. Off. Agric. Chem. $56,781-782$

Würsch P., Del Vedovo S., Koellreutter B., 1986. Cell structure and starch nature as key determinants of the digestion rate of starch in legume. Amer. J. Clin. Nutr. 43, 25-29

\section{STRESZCZENIE}

\section{Strawność węglowodanów bobiku i grochów do końca jelita cienkiego świń}

Doświadczenie przeprowadzono na sześciu świniach o początkowym ciężarze ok. $34 \mathrm{~kg}$. Świnie, $\mathrm{z}$ przetokami przy końcu jelita cienkiego, żywiono przemiennie széścioma pólsyntetycznymi mieszankami składającymi się głównic z cukru i ze śrut różnych odmian nasion bobiku (Kamir i Alen), grochu (Kwestor i Sol) lub peluszki (Fidelia i Vatra). Nasiona badanych odmian byly jedynymi źródłami wielocukrów i białka $w$ dictach doświadczalnych.

Strawność skrobi grochu i peluszki była podobna (85-87\%), a bobiku w odmianie Kamir i Alen wyniosła odpowiednio 82 i $86 \%$. Strawność białka wszystkich strączkowych wahała się od 70 do $74 \%$. W jelicie cienkim $\alpha$-galaktozydy bobiku uległy fermentacji bakteryjnej do $83 \%$, a grochu i peluszki - do $93 \%$. Strawność jelitowa wiclocukrów nieskrobiowych badanych odmian wynosiła średnio okolo $39 \%$, a grochu i peluszki od 27 do $43 \%$. Ogólnie, nie stwierdzono różnic w strawności jelitowej glównych składników pokarmowych między peluszką i grochem, różniących się zawartością tanin. 